\title{
Escherichia coli heat-stable enterotoxin b (STb) in vivo internalization within rat intestinal epithelial cells
}

\author{
Vincent Labrie, Josée Harel, J. Daniel Dubreuil*
}

\begin{abstract}
Groupe de Recherche sur les Maladies Infectieuses du Porc, Département de Pathologie et Microbiologie, Faculté de Médecine Vétérinaire, Université de Montréal, 3200 rue Sicotte, CP 5000, Saint-Hyacinthe, Québec, Canada J2S 7C6
\end{abstract}

(Received 20 August 2001; accepted 27 November 2001)

\begin{abstract}
Heat-stable enterotoxin b (STb) is a low molecular weight toxin known to bind sulfatide, its receptor. The fate of STb bound to rat intestinal epithelium cells was followed using an anti-toxin gold labeled assay and transmission electron microscopy. The data suggest that STb toxin and the fusion protein maltose binding protein (MBP)-STb were internalized whereas its mutant I41E-M42R with reduced hydrophobicity did not show internalization. There was a significant difference in the mean of gold particles per field between rat intestine incubated with STb or the fusion protein MBP-STb and the negative control consisting of intestine incubated with PBS alone. No subcellular compartment seems to be particularly aimed by the toxin as gold particles were randomly distributed within the cell.
\end{abstract}

\section{Escherichia coli / STb enterotoxin / internalization}

Résumé - Internalisation in vivo de l'entérotoxine b (STb) d'Escherichia coli dans les cellules épithéliales d'intestin de rat. L'entérotoxine $b$ thermostable (STb) est une toxine de faible masse moléculaire qui se lie au sulfatide, son récepteur. À l'aide d'un essai avec un anticorps anti-STb marqué à l'or suivi d'une visualisation en microscopie électronique, nous avons observé les évènements suivant l'attachement de STb aux cellules épithéliales d'intestin de rat. La toxine STb et la protéine de fusion Maltose Binding Protein-STb (MBP-STb) ont été internalisées tandis que le mutant I41E-M42R avec une hydrophobicité réduite ne présentait pas d'internalisation. Nous avons observé une différence significative de la moyenne de particules d'or par champ entre l'intestin de rat incubé avec STb ou la protéine de fusion MBP-STb et le contrôle négatif, soit le tampon PBS seul. Aucun organelle cellulaire ne semble particulièrement visé par la toxine puisque les particules d'or étaient distribuées aléatoirement dans la cellule.

\section{Escherichia coli / entérotoxine STb / internalisation}

*Correspondence and reprints

Address until September 2002: Instituto Ricerche Immunobiologiche Siena, Chiron S.p.A., Via Fiorentina 1, 53100 Siena, Italy. Tel.: (39) 0577 243063; fax: (39) 0577 243564; e-mail: daniel.dubreuil@umontreal.ca 


\section{INTRODUCTION}

Heat-stable enterotoxin b (STb) secreted by enterotoxigenic strains of Escherichia coli is a low molecular weight peptide that produces secretory diarrhea in animals by altering the intestinal electrolyte balance [4]. STb is a 48-amino-acid polypeptide with a molecular weight of $5.2 \mathrm{kDa}$. Nuclear magnetic resonance (NMR) studies of STb have established a structure having two antiparallel alphahelices motifs separated by a loop. There is an amphipathic helicoidal stretch between residues 10 to 22 , exposing several polar side chains to the solvent. Facing it, is an hydrophobic helix extending from residues 38 to 44 [17]. STb enterotoxin forms hexamers and heptamers through hydrophobic bonds between the C-terminal hydrophobic $\alpha$-helix [14]. Mutagenesis studies have demonstrated the importance of amino acid I41 and M42 in enterotoxicity and oligomerisation [13].

$\mathrm{STb}$ binds to a functional sulfatide receptor located in brush border membranes [16]. In vitro studies have shown that the intestinal secretion pathway involves the activation of a GTP-binding regulatory protein ( $G_{\alpha \text { i3 }}$ protein) sensitive to pertussis toxin. This action results in an intracellular calcium elevation through a receptor-dependent ligand-gated $\mathrm{Ca}^{2+}$ channel [3]. The ensuing high level of intracellular $\mathrm{Ca}^{2+}$ is presumably involved in activation of a calmodulin-dependent protein kinase II (CaMK II) which could open an undetermined ionic channel [8]. In addition, intracellular concentration of $\mathrm{Ca}^{2+}$ may regulate phospholipases $\mathrm{A}_{2}$ and $\mathrm{C}$ which catalyze the release of arachidonic acid from the membrane phospholipids, and ultimately the formation of prostaglandin $\mathrm{E}_{2}$ $\left(\mathrm{PGE}_{2}\right)$ known as a secretory agent $[7,12$, 15]. The steps following the attachment of $\mathrm{STb}$ to its receptor remain unsolved. In addition to STb toxin, a fusion protein with the maltose binding protein (MBP-STb) previously shown to be active in vivo [6] and a STb mutant (I41E-M42R) that could not form oligomers [14] were also evaluated in vivo for internalization. We hypothesize that after docking to sulfatide, $\mathrm{STb}$ has to cross the plasmic membrane to possibly activate a $\mathrm{G}$ protein and, in this study, experiments were conducted to prove or refute this point.

\section{MATERIALS AND METHODS}

\subsection{Ligated rat jejunum loop assay}

Enterotoxicity tests were conducted using a ligated rat jejunum loop assay as described previously [5].

\subsection{STb toxin purification}

In order to obtain pure $\mathrm{STb}$ mutant (I41E-M42R) and native STb enterotoxin, the peptides were produced and purified according to a previously described method [10]. The mutant was produced by oligonucleotide-directed site-specific mutagenesis using the USE Mutagenesis Kit from Pharmacia Biotech. as already described [13]. The fusion protein (MBP-STb) was purified by ionic chromatography following an already described method [6].

\subsection{Anti-STb gold conjugate}

Rabbit monospecific polyclonal antiserum against $\mathrm{STb}$ was produce according to the method of Handl et al. [11]. Colloidal gold particles approximately $18 \mathrm{~nm}$ in diameter were prepared according to the method of Frens [9]. The minimal dilution of anti-STb serum required to stabilize a fixed amount of colloidal gold adjusted to pH 6.9 was determined by construction of an adsorption isotherm. It was found that a ratio of 1:100 (antisera: colloidal gold) was just sufficient to prevent salt-induced flocculation. After centrifugation at $45000 \times g$ 
for $30 \mathrm{~min}$ at $4{ }^{\circ} \mathrm{C}$, the final pellet was resuspended in $1 / 10$ of the original volume and stored at $4{ }^{\circ} \mathrm{C}$. The distribution of intracellular gold particles was quantitated by calculating the number of black dots per field at a magnification of $30000 \times$.

\subsection{Electron microscopy}

In brief, pieces of cut tissue were fixed in $1 \%$ glutaraldehyde and 2\% paraformaldehyde in $0.1 \mathrm{M}$ sodium cacodylate buffer ( $\mathrm{pH}$ 7.2) for $2 \mathrm{~h}$, and then washed 5 times with buffer alone. After dehydration in an alcohol series, the alcohol was progressively replaced by $100 \%$ Unicryl at $4{ }^{\circ} \mathrm{C}$. After the change of Unicryl in $24 \mathrm{~h}$, pieces of tissue were covered with Unicryl for polymerization under UV rays at $4{ }^{\circ} \mathrm{C}$ for $72 \mathrm{~h}$.

Sections were cut using a diamond knife on a Reichert-Jung Ultracut ultramicrotome. After a blocking step with $1 \%$ ovalbumin in buffer A (0.1 M phosphate buffer $\mathrm{pH} 7.4$, $150 \mathrm{mM} \mathrm{NaCl}$ and $0.05 \%$ Tween 20) for $1 \mathrm{~h}$ at room temperature, sections were then incubated with anti-STb gold conjugate diluted 1/6 in buffer B (20 mM Tris pH 7.6, $150 \mathrm{mM} \mathrm{NaCl}, 0.05 \%$ Tween 20 and $0.5 \%$ ovalbumin) overnight. Following washing steps, sections were stained with uranyl acetate and lead citrate and viewed in a Phillips 201 electron microscope operated at an accelerating voltage of $80 \mathrm{kV}$.

\section{RESULTS}

The distribution of toxin-anti-STb-gold particles complex on the surface and within the intestinal epithelial cells after STb incubation for $3 \mathrm{~h}$ in the rat loop model is shown in Figure 1. Gold particles were mostly found intracellularly and were present in fewer number bound to the plasmic membrane. The toxin molecules at the surface of cells could be docked to the plasma membrane via its sulfatide receptor. As shown in Table I, we observed for both proteins test-
Table I. Internalization of STb and MBP-STb within rat jejunum epithelial cells as revealed with anti-STb labeled with gold particles.

\begin{tabular}{lc}
\hline Sample tested & $\begin{array}{c}\text { a Mean of intracellular } \\
\text { gold particles per field }\end{array}$ \\
\hline Control (PBS) & 7.7 \\
STb & 45.6 \\
MBP-STb & 46.7 \\
\hline
\end{tabular}

a Average of 60 electron microscope fields. The values are the means of three experiments.

ed, STb and a fusion protein MBP-STb, a significant internalization process using the statistical test ANOVA, for $\mathrm{F}(2,174)=51.5$, $p<0.0001$. Moreover, the fusion protein MBP-STb seemed to behave like the STb toxin as the means of gold particles per field were not significantly different. Those assays were repeated twice and similar results were obtained.

In another experiment, internalization of mutant I41E-M42R was compared to native STb toxin. As observed in Table II, the mean number of gold particles per field for the mutant I41E-M42R was significantly different $(p<0.0005)$ from STb toxin but not significantly different from the PBS negative control according to the statistical Student $t$ test. The relative percentage of internalization for the STb mutant was 7.4\% compared to the native STb toxin. No subcellular compartment seems to be particularly aimed by the toxin as gold particles were randomly distributed within the cell.

\section{DISCUSSION}

The present study presents direct evidence of $\mathrm{STb}$ internalization in an in vivo animal model. Using an anti-toxin gold labeled assay followed by visualization by transmission electron microscopy, we have demonstrated that STb entered intestinal 

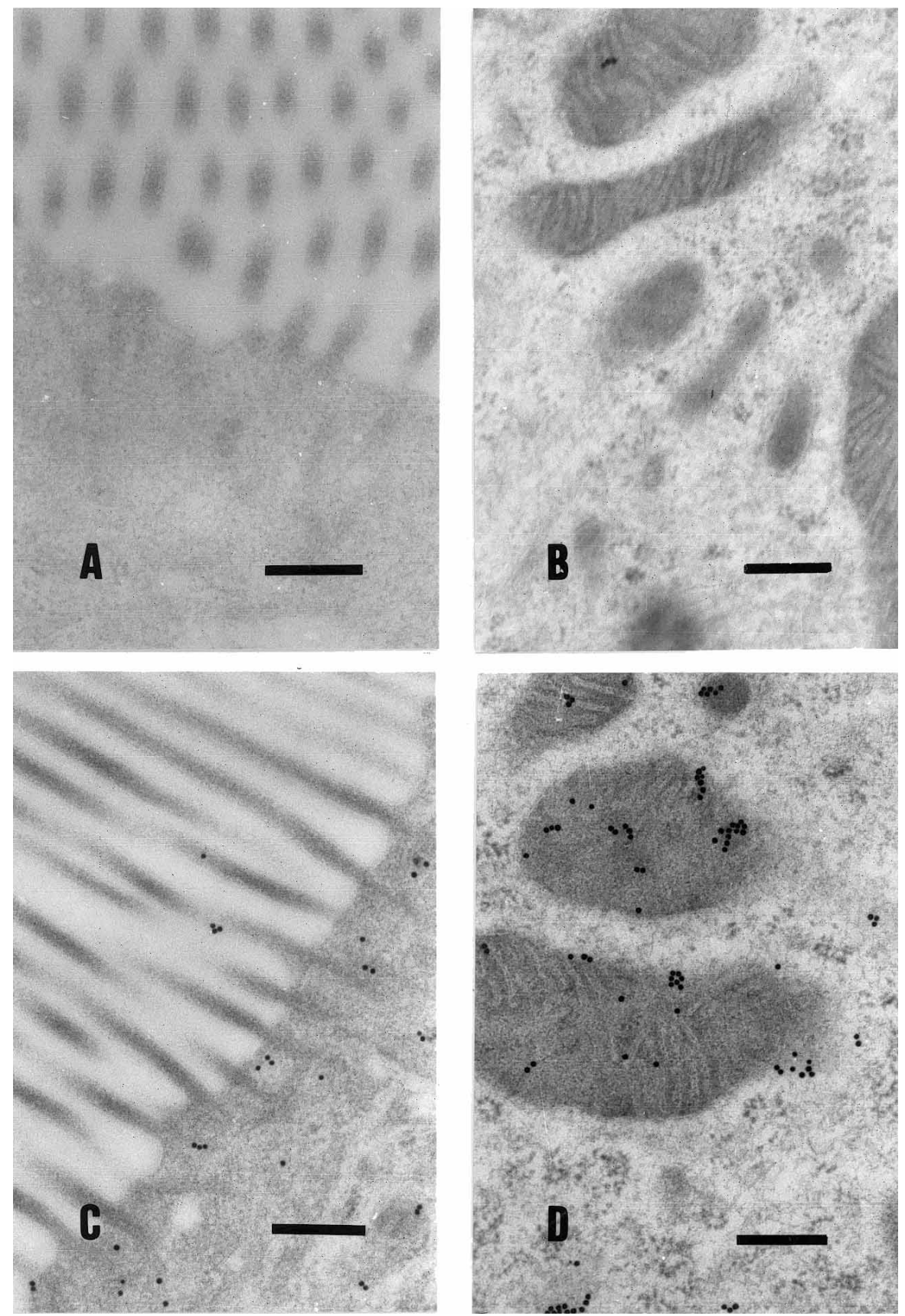

Figure. 1. Distribution within epithelial cells of rat intestine of STb toxin as detected by gold labeled anti-STb. A and B represent PBS negative controls whereas C and D are STb-treated rat intestine. In $\mathrm{A}$ and $\mathrm{C}$, intestinal microvilli are shown whereas in $\mathrm{B}$ and $\mathrm{D}$, we can observe intracellular compartments. Bars $=2.5 \mu \mathrm{m}$. 
Table II. Internalization of STb and I41EM42R mutant within rat jejunum epithelial cells as revealed with anti-STb labeled with gold particles.

\begin{tabular}{lc}
\hline Sample tested & $\begin{array}{c}{ }^{a} \text { Mean of intracellular } \\
\text { gold particles per field }\end{array}$ \\
\hline Control (PBS) & 32.3 \\
STb & 44.2 \\
I41E-M42R mutant & 33.2 \\
\hline
\end{tabular}

a Average of 60 electron microscope fields. The values are the means of two experiments.

epithelial cells within the $3 \mathrm{~h}$ incubation period. This supports the fact that the maximum activity of STb occurred after $3 \mathrm{~h}$ of incubation [12]. A study by Chao and Dreyfus on the binding of ${ }^{125} \mathrm{I}-\mathrm{ST}$ toxin to rat intestinal epithelial cells indicated that following its interaction with epithelial cells, approximately $50-80 \%$ of the toxin remained stably associated with the cells [2]. This observation, according to the authors, could imply that the toxin was partitioned into the membrane or could also be internalized by the cells. In a previous study, the same authors had shown that after adding STb to T84 and HT29 cells in culture, a significant fraction of the added toxin was free in cytoplasm as indicated by a reaction involving anti-STb antibody and a goat anti-rabbit IgG-Rhodamine conjugate. From their results, they concluded that the bound toxin could probably directly traverse the plasmic membrane [1]. The staining of the cytoplasm was diffuse indicating that STb did not appear to preferentially associate with membrane vesicles or cellular organelles.

In our study, STb and MBP-STb, a fusion protein, were equally internalized within rat intestinal epithelial cells in vivo. This corroborates the results obtained in a previous study with those molecules as both were biologically active in vivo [6].

The results obtained for STb mutant I41E-M42R suggest that the hydrophobic $\alpha$-helix via the amino acids residues I41 and M42 could be involved in the internalization process. Knowing that these residues (I41 and M42) are necessary for oligomerization [14], the role of these residues could be either due to their direct implication in hydrophobic interaction during the passage through the plasmic membrane or the requirement for the oligomerization process before internalization could occur. Interestingly, since these residues (I41 and M42) have also been shown to be important for enterotoxicity [13], perhaps this may mean that internalization is crucial for enterotoxicity of STb. Many toxins that show internalization activity possess hydrophobic or amphipathic alpha helical structures as observed for STb toxin. Further studies with reporter proteins such as the green fluorescent protein (GFP), for example, could be useful to detail the pathway taken by STb during the internalization process.

\section{ACKNOWLEDGEMENTS}

This work was supported by grant OGP0139070 to J.D. Dubreuil from the Natural Sciences and Engineering Research Council of Canada (NSERC) and grant 93-ER-0214 from Fonds pour la Formation au Chercheurs et l'Aide à la Recherche (FCAR). V. Labrie is the recipient of a doctorate studentship from FCAR. We thank C. Lussier for her valuable collaboration with the electronic microscope; G. Beauchamp for his helpful advices with statistical analysis; and H.-E. Beausoleil for his valuable help. The authors thank Dr. M. Jacques for his help with the electron microscopy protocol used in this study. 


\section{REFERENCES}

[1] Chao K.L., Dreyfus L.A., Interaction of Escherichia coli heat-stable enterotoxin B with cultured human intestinal epithelial cells, Infect. Immun. 65 (1997) 3209-3217.

[2] Chao K.L., Dreyfus L.A., Interaction of Escherichia coli heat-stable enterotoxin B with rat intestinal epithelial cells and membrane lipids, FEMS Microbiol. Lett. 172 (1999) 91-97.

[3] Dreyfus L.A., Harville B., Howard D.E., Shaban R., Beatty D.M., Morris S.J., Calcium influx mediated by the Escherichia coli heat-stable enterotoxin $\mathrm{B}\left(\mathrm{ST}_{\mathrm{B}}\right)$, Proc. Natl. Acad. Sci. USA 90 (1993) 3202-3206.

[4] Dubreuil J.D., Escherichia coli STb enterotoxin, Microbiology 143 (1997) 1783-1795.

[5] Dubreuil J.D., Fairbrother J.M., Lallier R., Larivière S., Production and purification of heat-stable enterotoxin b from a porcine Escherichia coli strain, Infect. Immun. 59 (1991) 198-203.

[6] Dubreuil J.D., Letellier A., Harel J., A recombinant Escherichia coli heat-stable enterotoxin b $(\mathrm{STb})$ fusion protein eliciting neutralizing antibodies, FEMS Immunol. Med. Microbiol. 13 (1996) 317-323.

[7] Fujii Y., Kondo Y., Okamoto K., Involvement of prostaglandin E2 synthesis in the intestinal secretory action of Escherichia coli heat-stable enterotoxin II, FEMS Microbiol. Lett. 130 (1995) 259-265.

[8] Fujii Y., Nomura T., Yamanaka H., Okamoto K., Involvement of $\mathrm{Ca}(2+)$-calmodulin-dependent protein kinase II in the intestinal secretory action of Escherichia coli heat-stable enterotoxin II, Microbiol. Immunol. 41 (1997) 633-636.
[9] Frens G., Controlled nucleation for the regulation of the particle size in monodisperse gold suspension, Nature 241 (1973) 20-22.

[10] Handl C.E., Harel J., Flock J.I., Dubreuil J.D., High yield of active STb enterotoxin from a fusion protein (MBP-STb) expressed in Escherichia coli, Protein Expr. Purif. 4 (1993) 275-281.

[11] Handl C., Ronnberg B., Nilsson B., Olsson E., Jonsson H., Flock J.I., Enzyme-linked immunosorbent assay for Escherichia coli heat-stable enterotoxin type II, J. Clin. Microbiol. 26 (1988) 1555-1560.

[12] Hitotsubashi S., Fujii Y., Yamanaka H., Okamoto K., Some properties of purified Escherichia coli heat-stable enterotoxin II, Infect. Immun. 60 (1992) 4468-4474.

[13] Labrie V., Beausoleil H.E., Harel J., Dubreuil J.D., Binding to sulfatide and enterotoxicity of various Escherichia coli STb mutants, Microbiology 147 (2001) 3141-3148.

[14] Labrie V., Harel J., Dubreuil J.D., Oligomerization of Escherichia coli enterotoxin b through its C-terminal hydrophobic alpha-helix, Biochem. Biophys. Acta 1535 (2001) 128-133.

[15] Peterson J.W., Whipp S.C., Comparison of the mechanisms of action of cholera toxin and the heat-stable enterotoxins of Escherichia coli, Infect. Immun. 63 (1995) 1452-1461.

[16] Rousset É., Harel J., Dubreuil J.D., Sulfatide from the pig jejunum brush border epithelial cell surface is involved in binding of Escherichia coli enterotoxin b, Infect. Immun. 66 (1998) 5650 5658.

[17] Sukumar M., Rizo J., Wall M., Dreyfus L.A., Kupersztoch Y.M., Gierasch L.M., The structure of Escherichia coli heat-stable enterotoxin b by nuclear magnetic resonance and circular dichroism, Protein Sci. 4 (1995) 1718-1729.

To access this journal online: www.edpsciences.org 